\title{
Study on the Impact of Elements in Water on the Diversity of Water Mites (Acari, Hydrachnidia) Species
}

\author{
Ferruh Aşçı1 ${ }^{1}$, Muhammet Bahadır ${ }^{2}$, Gülderen Uysal Akkuş ${ }^{3}$ \\ ${ }^{1}$ Department of Molecular Biology and Genetics, Afyon Kocatepe University, Afyonkarahisar, Turkey \\ ${ }^{2}$ Department of Geography, Ondokuz Mayıs University, Samsun, Turkey \\ ${ }^{3}$ Department of Chemistry, Afyon Kocatepe University, Afyonkarahisar, Turkey \\ Email: $\underline{f \text { asci@aku.edu.tr }}$
}

Received 20 March 2015; accepted 2 April 2015; published 7 April 2015

Copyright (C) 2015 by authors and Scientific Research Publishing Inc.

This work is licensed under the Creative Commons Attribution International License (CC BY).

http://creativecommons.org/licenses/by/4.0/

(c) (i) Open Access

\begin{abstract}
In this study the distribution and relationships of element levels in water and water mite species (Acari, Hydrachnidia) selected as model organisms have been examined in two different lakes. Water samples from Eber and Karamik Lakes were analyzed with ICP (ICP-OES Instrument Spectro Genesis Fee, Germany) equipment to determine the element levels in the water. That impact level of these elements on the distribution of species was discussed. Change in the lake water composition was not a significantly determining factor in the number of species and diversities of water mites. However, eutrophication was observed to be a determining factor on the distribution of species.
\end{abstract}

\section{Keywords}

Water Mite, Distribution of Species, ICP, Water Analysis, Lake, Turkey

\section{Introduction}

This study was carried out in Eber and Karamık Lakes which are within the boundaries of Afyonkarahisar province. The water mite fauna of both lakes was determined. Water samples were taken from two parallel points of each lake and analyzed with ICP equipment. In addition, the lake formations, geomorphologic characteristics and climatic conditions were studied. The findings for each lake were compared and a relationship in respect of species distribution and water parameters was carried out.

The water mites belonged to a polyphyletic Acari sub-group. There is a special significance in determining 
the habitats and communities in stagnant waters such as lakes and ponds and those in flowing waters. Water mites which are spreading in almost all internal waters are exploited as determinant species to confirm clean water sources. Adult water mites are predatory while the larva exploits insects and mollusks in a parasitical existence [1]-[4].

Eber Lake is a tectonic lake among a group of shallow lakes. The depth of the lake is between 2 - $3 \mathrm{~m}$ and the deepest place does not exceed $5 \mathrm{~m}$. Eber Lake is $965 \mathrm{~m}$ above sea level. The lake water is polluted because of the high amount of domestic sewage delivered by Akarçay stream which feeds the lake. In addition to this, eutrophication due to aridification of the climate as well as various pollutants has led to the forming of various algae on the surface of the lake and particularly the shore. Continental climate conditions prevail in the area where the lakes are located. In addition, subject to the global warming trend prevalent in the world, the water level of the lakes has dropped rapidly and the lakes have gone into a drying process [5]-[7].

Karamık Lake, on the other hand, was formed as a result of fault movement caused by alpine tectonic movements. Karamık Lake is surrounded by mountain areas in the north and south. Lake Karamık is formed in the lowest part of this depression surrounded by mountainous areas [8] [9]. Like Eber Lake, Karamık Lake is also among the shallow lakes group. A major area of the lake which does not exceed $3 \mathrm{~m}$ in depth is covered with reeds and marsh areas. A study of the climate characteristics of the lake and perimeter reveals the impact of continent climate in the region. A calculation performed according to index values with hot summer temperatures of $20^{\circ} \mathrm{C}-25^{\circ} \mathrm{C}$ and cold winter temperatures $\left(0^{\circ} \mathrm{C}-3^{\circ} \mathrm{C}\right)$ the region is categorized in Erinç's Macroclimate regions of Turkey as "Central Anatolian Steppe Climate”.

Karamık and Eber Lakes are located in the Lakes Area of Turkey and their formation is of tectonic origin. While these lakes are geologically young lakes (Quarternary) they are classified as lakes which are past their biological prime regarding production and lifespan [9]. As for climatic characteristics both lakes are located in a semi-arid continental climate area with rainfall values between $300 \mathrm{~mm}$ and $500 \mathrm{~mm}$ and total annual average amount of vaporization exceeding $1000 \mathrm{~mm}$ with temperatures exceeding $25^{\circ} \mathrm{C}$ on average during summer months [10].

An examination of the water characteristics and pollution levels of Eber and Karamik lakes reveals that according to the water pollution regulation the polluted water is categorized as Class III (2000 - 100,000 in 100 ml) for coliform bacteria pollution. Both lakes are classified as Class II (100 - 20,000 in $100 \mathrm{ml}$ ) for fecal coliform content. A census performed with reproduction results achieved with Blood agar and bile-eskulin agar at $37^{\circ} \mathrm{C}$ and $45^{\circ} \mathrm{C}$ revealed that the ratio of D group fecal streptococci was $72 \%$ in Eber Lake and $24 \%$ in Karamik Lake [11]. According to these results domestic waste is being discharged intensely into Eber Lake and as a result the eutrophication ratio of the lake continues to increase (Figure 1).

\section{Materials and Methods}

Water mites which are a significant biological indicator organism for determining clean water sources were selected as a model species in the study. The fact that mites bear the characteristics of indicator organisms had a major impact on the selection of the water mite as a model species. Water mites were collected from the lakes at particular intervals and a species determination was executed. In addition water samples were taken from the lakes and analyzed with ICP (ICP-OES Instrument Spectro Genesis Fee, Germany). Thus the water characteristics and the amounts of contained elements in both lakes were determined. In addition, both lakes were studied for geomorphologic formations, climate characteristics and ecosystems.

The collected samples were determined by placing them into storage bottles containing koenike fluid (5 parts of glycerine, 2 parts of acetic acid, 3 parts distilled water) with the help of a pipette; the bottles were then placed into white tubs.

After the samples had become sufficiently transparent fixation fluid was placed on a slide and glycerin was added. Then under a stereomicroscope the genital structure, structures such as capitulum, chelicerae, palp, dorsal plate, eye capsules were prepared with the help of needles and fine-tipped forceps and drawn under special microscopes in order to establish the gender and species of the collected water mites. The determination of species was made according to these drawings [1].

Correlation analyses were carried out with the acquired data in order to establish the relationship between distribution of water mite species and water parameters. Correlation analysis is a statistical method used in determining the level of the relationship between different variables. 


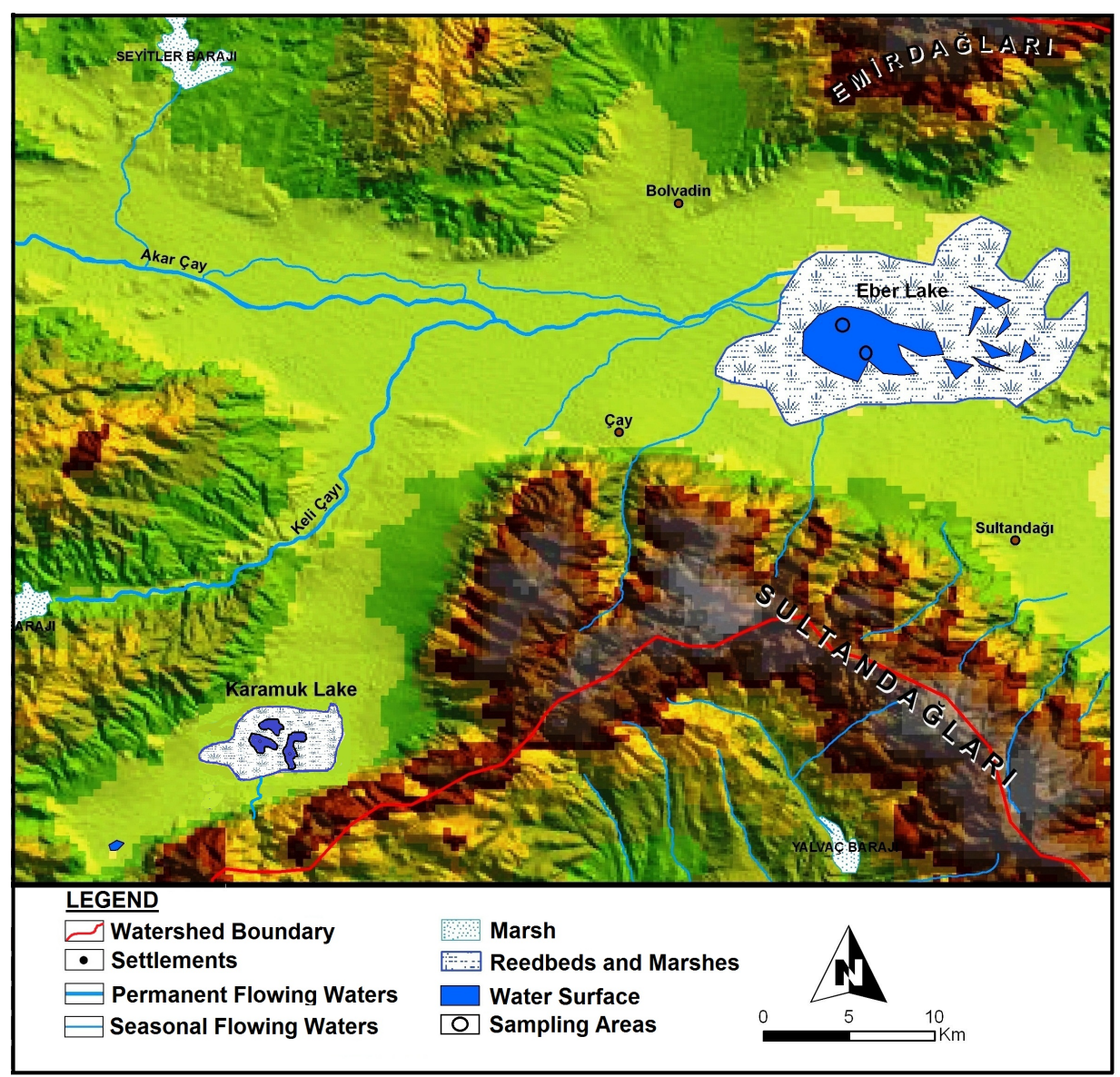

Figure 1. Eber and Karamık Lakes location map and sampling points.

Correlation analysis is a statistical method used in determining the degree and direction of the relationship between two variables. The independency of the variable is not taken into consideration. There are various correlation coefficients such as the Pearson correlation coefficient, Canonical correlation coefficient, partial correlation coefficient used to calculate in various ways for different purposes. Out of these the Pearson correlation coefficient is shown as $r$ and calculated with a formula. The correlation coefficients are taken as values which vary between -1 and $+1(-1 \leq r \leq+1)$. The coefficient is 0 if there is no relationship, 1 if the relationship is full and strong and -1 if the relationship is full and inverse [12].

While +1 shows that there is a directly related full relationship between variables, if one variable increases or decreases the other variable will increase or decrease in the same proportion. However, if the correlation coefficient is -1 this indicates that there is a full inverse relationship between the variables and if one variable increases the other variable decreases in the same proportion. A correlation coefficient of zero $(r=0)$ indicates that there is no relationship between the variables. The correlation coefficient is calculated with the formula given below by using $r, n=$ number of observations while correlation values are used for, $x$ and $y$ [12] [13].

\section{Results}

As a result of the analysis performed on water mite species from both lakes it was observed that Karamık Lake was host to more water mite species whereas this number had decreased for Eber Lake. While 21 water mite species were detected in Karamık Lake the number remained as 8 for Eber Lake (Table 1). The water mite species in Karamık Lake were collected from different levels and depths while those from Eber Lake were mainly species which preferred plenty of oxygen and were collected from areas close to the surface of the water [14] [15].

Table 1 indicates that the number of water mite species detected in Karamık Lake are at the expected 
Table 1. Species of water mites determined in Karamı and Eber Lakes (Acari, Hydrachnidia).

\begin{tabular}{|c|c|}
\hline Karamık Lake & Eber Lake \\
\hline Hydrachna skorikowi & Hydrachna skorikowi \\
\hline Hydrachna globosa & Hydrachna globosa \\
\hline Hydrachna processifera & Hydrachna conjecta \\
\hline Eylais setosa & Hydrachna piersigi \\
\hline Eylais extendens & Eylais infundubulifera \\
\hline Hydryphantes dispar & Hydryphantes flexuosus \\
\hline Hydryphantes flexuosus & Georgella helvetica \\
\hline Georgella helvetica & Hydrodroma despiciens \\
\hline \multicolumn{2}{|l|}{ Hydrodroma despiciens } \\
\hline \multicolumn{2}{|l|}{ Limnesia fulgida } \\
\hline \multicolumn{2}{|l|}{ Unionicola crassipes } \\
\hline \multicolumn{2}{|l|}{ Unionicola minor } \\
\hline \multicolumn{2}{|l|}{ Piona alpicola contraversiosa } \\
\hline \multicolumn{2}{|l|}{ Arrenurus cuspidifer } \\
\hline \multicolumn{2}{|l|}{ Arrenurus bruzelii } \\
\hline \multicolumn{2}{|l|}{ Arrenurus rodrigensis } \\
\hline \multicolumn{2}{|l|}{ Arrenurus affinis } \\
\hline \multicolumn{2}{|l|}{ Arrenurus maculator } \\
\hline \multicolumn{2}{|l|}{ Arrenurus cuspidator } \\
\hline \multicolumn{2}{|l|}{ Arrenurus suecius } \\
\hline Arrenurus globator & \\
\hline
\end{tabular}

level while the number for Eber Lake is far below the expected level. In terms of habitats, the species inhabiting Eber Lake were surface species [11]. The fact that the number of species discovered in Karamık Lake indicates that the lake is in a state of ecologic balance and that the species establishing the limnofauna are not about to be seriously threatened in the near future.

A correlation analysis was performed in order to determine the relationship level between the distribution of water mite species and water parameters. As a result of the analysis executed for each of the parameters of water an insignificant relationship was observed as a result of the negative influence of heavy metals contained among the water elements on the abundance of water mite species (-0234). Accordingly, it can be concluded that if the amount of heavy metals in the lake water increases the number of water mite species will decrease. The correlation values between other elements and distribution of water mite species appeared to be positive and again insignificant (0.256). Variance and regression analysis produced similar conclusions. According to these results, the amount of elements in lake waters is too insignificant to limit the habitats of the creatures and their impact level is very low.

The water samples taken from Karamı and Eber Lakes were analyzed with ICP (ICP-OES Instrument Spectro Genesis Fee, Germany). Thus the elements in the lake waters were analyzed at ppm level. The element values in both lakes were very similar to each other. It was observed that the level of these elements found in very small quantities were close to natural levels and not sufficient to have any impact on the diversity of species.

The fact that the level of heavy metals restricting the lives of living creatures is very low is an important indicator showing that there is no negative impact on living creatures (Table 2). In terms of other values it is evident that there are no significant extreme values. In statistical analysis extreme values point to a low significance level relationship. According to these results, the amount of values contained in the water is not sufficient to have a negative impact on the species. 
Table 2. The analysis results for water samples from Karamık and Eber Lakes analyzed with ICP (ICP-OES Instrument Spectro Genesis Fee, Germany).

\begin{tabular}{|c|c|c|c|c|c|c|c|c|c|c|c|c|}
\hline \multirow{2}{*}{ Sample } & $\mathrm{Al}$ & $\mathrm{Ba}$ & $\mathrm{Be}$ & $\mathrm{Ca}$ & $\mathrm{Cd}$ & Co & $\mathrm{Cr}$ & $\mathrm{Cu}$ & $\mathrm{Fe}$ & $\mathrm{Ga}$ & $\mathrm{K}$ & $\mathrm{Li}$ \\
\hline & $\mathrm{mg} / \mathrm{l}$ & $\mathrm{mg} / \mathrm{l}$ & $\mathrm{mg} / \mathrm{l}$ & $\mathrm{mg} / \mathrm{l}$ & $\mathrm{mg} / \mathrm{l}$ & mg/l & $\mathrm{mg} / \mathrm{l}$ & mg/l & $\mathrm{mg} / \mathrm{l}$ & $\mathrm{mg} / \mathrm{l}$ & $\mathrm{mg} / \mathrm{l}$ & $\mathrm{mg} / \mathrm{l}$ \\
\hline 1 PPM & 0.931 & 1.225 & 0.954 & 0.870 & 0.980 & 0.977 & 0.960 & 0.960 & 0.979 & 0.887 & 0.809 & 0.834 \\
\hline Eber Lake & 0.240 & $<-0.658$ & 0.145 & 52.241 & 0.060 & 0.035 & 0.031 & 0.107 & 0.232 & 0.316 & 21.539 & 0.586 \\
\hline Eber Lake & 0.276 & $<-0.664$ & 0.145 & 53.079 & 0.060 & 0.035 & 0.033 & 0.113 & 0.201 & 0.334 & 20.482 & 0.584 \\
\hline Karamık Lake & 0.281 & $<-0.677$ & 0.144 & 31.725 & 0.059 & 0.035 & 0.031 & 0.102 & 0.281 & 0.322 & 7.719 & 0.554 \\
\hline Karamık Lake & 0.331 & $<-0.630$ & 0.144 & 53.664 & 0.059 & 0.036 & 0.033 & 0.101 & 0.131 & 0.323 & 17.750 & 0.577 \\
\hline Karamık Lake & 0.326 & $<-0.655$ & 0.144 & 37.641 & 0.059 & 0.040 & 0.034 & 0.106 & 0.151 & 0.323 & 31.410 & 0.652 \\
\hline \multirow{2}{*}{ Sample } & $\mathrm{Mg}$ & $\mathrm{Mn}$ & $\mathrm{Na}$ & $\mathrm{Ni}$ & $\mathrm{Pb}$ & Se & $\mathrm{Sr}$ & $\mathrm{Te}$ & $\mathrm{Tl}$ & $\mathrm{Zn}$ & $\mathrm{Bi}$ & \\
\hline & $\mathrm{mg} / \mathrm{l}$ & $\mathrm{mg} / \mathrm{l}$ & $\mathrm{mg} / \mathrm{l}$ & $\mathrm{mg} / \mathrm{l}$ & $\mathrm{mg} / \mathrm{l}$ & mg/l & $\mathrm{mg} / \mathrm{l}$ & mg/l & $\mathrm{mg} / \mathrm{l}$ & $\mathrm{mg} / \mathrm{l}$ & $\mathrm{mg} / \mathrm{l}$ & \\
\hline 1 PPM & 0.995 & 0.947 & 1.164 & 0.955 & 1.002 & 0.933 & 0.961 & 0.982 & 0.962 & 0.968 & 0.999 & \\
\hline Eber Lake & 37.148 & 0.152 & 23.395 & 0.078 & $<0.003$ & 0.368 & 0.432 & 0.263 & 0.205 & 0.318 & $<0.019$ & \\
\hline Eber Lake & 35.676 & 0.136 & 23.175 & 0.091 & $<0.002$ & 0.350 & 0.429 & 0.325 & 0.233 & 0.574 & 0.057 & \\
\hline Karamık Lake & 28.721 & 0.119 & 15.411 & 0.087 & $<-0.008$ & 0.339 & 0.278 & 0.282 & 0.234 & 0.312 & $<0.034$ & \\
\hline Karamık Lake & 54.086 & 0.127 & 38.103 & 0.085 & $<-0.015$ & 0.764 & 0.396 & 0.318 & 0.220 & 0.300 & $<0.034$ & \\
\hline Karamık Lake & $>79.257$ & 0.122 & $>74.446$ & 0.085 & $<0.009$ & 0.751 & 0.301 & 0.290 & 0.244 & 0.360 & $<0.016$ & \\
\hline
\end{tabular}

\section{Discussion}

The study regarding the relationship and impact level of water elements on the distribution of water mite species revealed that there is intense eutrophication in Eber Lake due to excessive nitrogen and phosphate domestic waste [11]. In fact as a result of eutrophication putrefaction in the lake has increased and the pollution level has reached an alarming level. However, it was observed that the level of heavy metals did not have a significant impact on the distribution of species. The fact that the water mite species determined in Eber Lake are those which swim actively near the lake surface strengthens our thesis. While the amount of domestic waste discharging into Eber Lake is excessive, the same situation is not valid for Karamık Lake.

The fact that the statistical significance of determining the distribution of water mite species with water elements in Eber and Karamık lakes is low supports the opinion that the habitats and diversity of water mite species rather depend on other factors. In particular a significance relationship of low level in terms of statistical analysis was found between the elements of both lake waters and abundance of water mite species. This indicates that other factors which determine the abundance of species in the lakes must be considered. In fact, while a negative relationship was determined in both lakes in terms of heavy metals and water mite distribution, other metals were observed to have a positive effect. For these reasons it is clear that the primary factor determining the abundance of water mite species in the lakes is the eutrophication of the lake waters.

Since sewage discharged into Eber Lake in Afyonkarahisar receives treatment before discharge the amounts of nitrogen and phosphorous compounds in this lake are rather high. This in turn has increased the eutrophication in the lake a lot. As a result, the amount of oxygen in the lake has decreased quite a lot which in turn has resulted in putting species with low oxygen tolerance under pressure [11]. The fact that the water mite species discovered within the scope of our study and found in Eber Lake are such which are found on the surface areas of pelagic regions proves this point.

No significant eutrophication was observed in Karamık Lake. The reason for this is that no domestic and industrial waste is discharged into Karamık Lake. The fact that the water mite species found in Karamık Lake belong to both the pelagic region as well as the benthic region indicates that the ecologic characteristics of this lake do not have an adverse impact on the life and variety of species.

Both lakes have a similar geomorphological formation and age and are situated within the same climate zone. Water depths are close to each other and range between 1 and 3 meters. It was observed that the geographical 
factors of these two lakes had no bearing on the differences between species diversity and distribution.

\section{References}

[1] Aşçı, F., Bursalı, A. and Özkan, M. (2007) Afyonkarahisar ili su kenesi (Acari, Hydrachnidia) faunası. Süleyman Demirel Üniversitesi, Eğirdir Su Ürünleri Fakültesi Dergisi, 2-3, 46-49.

[2] Güderoğlu, M. (2006) Systematic Study of the Water Mite Fauna in the Flowing Waters of Akdağ National Park (Sandıkl1, Afyonkarahisar). Post Graduate Thesis, Afyon Kocatepe University, Afyonkarahisar.

[3] Prasad, V. and Cook, D.R. (1972) Water Mite Larvae. Memoirs of the American. Entomological Institue, Michigan, 18, 1-326.

[4] Gerecke, R. (2003) Water Mites of the Genus Atractides Koch, 1837 Acari: Parasitengona: Hygrobatidae in the Western Palaeretic Region Revision. Zoological Journal of the Linnean Society, 138, 141-378. http://dx.doi.org/10.1046/j.1096-3642.06-0.00051.x

[5] Türkeş, M., Koç, T. and Sarış, F. (2007) Total Rainfall Intensity in Turkey and Temporal and Spatial Analysis of Sequences of Changes and Trends. Journal of Geographical Sciences, 3, 57-73.

[6] Özdemir, M.A. and Bahadır, M. (2011) Hydro-Climatic Trend Analysis of Eber and Akşehir Lakes, Physical Geography Research; Systematic and Regional. Turkish Geography Authority Publications, 5, 181-198.

[7] Kadığlu, M. (1997) Trends in Surface Air Temperature Data Over Turkey. International Journal of Climatology, 17, 511-520. http://dx.doi.org/10.1002/(SICI)1097-0088(199704)17:5<511::AID-JOC130>3.0.CO;2-0

[8] Atalay, İ. (1977) A Structural, Geomorphologic and Soil Erosion Study for Sultandağları and Akşehir and Eber Lake Watersheds. Atatürk University Publication, Erzurum, 500.

[9] İleri, Ö. (1994) A Contemporary Study of the Sediments of Akşehir Lake. Postgraduate Thesis, Ankara University, Ankara.

[10] Kazancı, N., Nemec, W., İleri, Ö. and Kavuşan, G. (1994) A Sedimentologic Study of Akşehir and Eber Lakes for Improvement and Recovery Works. Ankara University Research Fund 91.05.01.01. No.B16762.

[11] Aşçı, F., Fıçıcı, E.K. and Konuk, M. (2009) A New Species of Water Mite Atractides (Atractides) turcicus sp. n. (Acari: Hydrachnidia: Hygrobatidae) from Turkey. Biologia, Section Zoology, 64, 1146-1149. http://dx.doi.org/10.2478/s11756-009-0191-7

[12] Orhunbilge, N. (1996) Applicable Regression and Correlation Analysis. Istanbul University Faculty of Business administration, No. 267, Istanbul.

[13] Aşçı, F. (2005) A Systematic, Ecologic and Microbiological Study of the Water Mites in Afyonkarahisar Province (Acari, Hydrachnellae) Afyon Kocatepe University Scientific Research Projects Commission Project No. 031.FENED.06) $86 \mathrm{p}$.

[14] Çömlekçi, N. (1989) Fundamental Statistics Principles and Techniques. Science Technical Publishers, Eskişehir.

[15] Ünal, B. (2010) A Systematic Study on the Water Mites of Eber Lake (Acari, Hydracnellae). Post Graduate Thesis, Afyon Kocatepe University, Afyonkarahisar. 